\title{
Integrated Arthropod Pest Management Systems for Human Health Improvement in Africa
}

\author{
Johann Baumgärtner ${ }^{1}$, Fritz Schulthess ${ }^{2}$ and Yunlong $\mathbf{X I A}^{3}$ \\ 'International Centre of Insect Physiology and Ecology (ICIPE), P. O. Box 17319, Addis Ababa, \\ Ethiopia; ${ }^{2}$ Postfach 112-4, Chur, Switzerland; ' ${ }^{3}$ International Centre of Insect Physiology and \\ Ecology (ICIPE), P. O. Box 30772, Nairobi 00100, Kenya
}

(Accepted 12 March 2003)

\begin{abstract}
In a sub-Saharan African context, limited natural resources, infectious diseases, including those transmitted by arthropod vectors, and chronic exposure to food contaminated with mycotoxinproducing fungi which, among others, are vectored by insects, are among the major constraints to human health. Thus, pest control should be an important component in human health improvement projects. It appears that the advantages of preventive over curative methods are rarely recognised in Africa, with more emphasis being given to the search for the 'silver bullet' than to integrated control approaches. Integrated pest management (IPM) systems can be assigned to different decisionmaking levels as well as to different integration levels, combining ecological (individual pest species, species communities, species assemblages) and management (crop, cropping systems, farms, communities) levels with the respective control systems. These levels produce a highly structured environment for decision-making, in which the use of modern information technology is important. Case studies show that IPM systems are developed and implemented at four integration levels, whereby most work is done on the lowest integration level, addressing a single pest or pest complex attacking a particular crop, group of livestock or human population, and the respective control measures undertaken. Coordinated efforts to develop and implement supplementary IPM systems at higher levels are concluded to be important elements in integrated pest management and a further contribution to human health improvement and poverty alleviation.
\end{abstract}

Key Words: IPM, human health, livestock, crops, information dissemination, decision making levels

Résumé-Dans le contexte de l'Afrique sub-Saharienne, les ressources naturelles limitées, les maladies infectieuses comprenant celles transmises par les arthropodes vecteurs, et l'exposition chronique aux aliments contaminés par les champignons produisant des mycotoxines lesquels, parmi d'autres, sont transmis par les insectes, font partie des contraintes majeures à la santé humaine. Ainsi, le contrôle des nuisibles devrait être une composante importante dans les projets d'amélioration de la santé humaine. Il apparaît cependant que les avantages des méthodes préventives par rapport aux méthodes curatives sont rarement reconnus en Afrique, avec plus d'attention accordée à la recherche de solutions miracles qu'aux approches de lutte intégrée. Les systèmes de lutte intégrée (LI) peuvent êtres attribués à plusieurs niveaux de décision aussi bien qu'à différents niveaux d'intégration, combinant les niveaux écologiques (nuisibles individuels, communautés d'espèces, assemblages d'espèces) et de gestion (culture, systèmes de culture, champs, communautés) avec les systèmes respectifs de contrôle. Ces niveaux produisent un environnement hautement structuré 
pour la prise de décision, dans laquelle l'utilisation des technologies modernes d'information est importante. Les études de cas ont montré que les systèmes de LI sont développés et implémentés à quatre niveaux $d$ 'intégration, à travers lesquels le gros du travail est fait au niveau le plus bas, s'adressant à une seule espèce de ravageur ou complexe de ravageurs qui attaquent une culture donnée, groupe d'animaux ou population humaine, et les mesures respectives de contrôle entreprises. Il est conclut que les efforts coordonnés pour développer et implémenter des systèmes de LI supplémentaires aux niveaux supérieurs sont des éléments importants de LI et constituent une contribution additionnelle pour l'amélioration de la santé humaine et la maîtrise de la pauvreté.

Mots Clés: lutte intégrée, santé humaine, bétail, cultures, diffusion d'information, niveaux de prise des decision

\section{INTRODUCTION}

$\mathrm{P}$ ests are considered as any of the various organisms such as fungi, arthropods, rodents and plants that harm crops or livestock or otherwise directly or indirectly interfere with the well-being of human beings (Anonymous, 1996). In a sub-Saharan African context, infectious diseases, including the ones transmitted by arthropod vectors, and limited natural resources, i.e. food (crops, livestock, fodder for livestock) and shelter (Begon et al., 1996), are among the major factors affecting human health (WRI, 1998; Baumgärtner et al., 2001).

Whereas global trends in human health improvements are positive, progress has been slow in sub-Saharan Africa and life expectancy still lags some 25 years behind the wealthiest nations (WRI, 1998). The malarial parasite transmitted by anopheline mosquitoes is the major cause of morbidity and mortality in the African region. Ninety-three percent of the 550 million people living on this continent are at risk; over $90 \%$ of the annual global 1.4-2.6 million deaths are reported from Africa (WHO, 1995). A second vector, the tsetse fly (Glossinidae), transmits human trypanosomosis-also known as sleeping sickness. With an estimated 300,000 cases per year, the disease has returned to its epidemic levels of the 1930s (Saini, 1999). In addition, in sub-Saharan Africa, people are being chronically exposed to unsafe levels of various mycotoxins produced by fungi such as Aspergillus spp. and Fusarium verticillioides Sacc. (Nirenberg), which are vectored by insects (Windels et al., 1975; Munkvold et al., 1997; Sétamou et al., 1998). These mycotoxins have carcinogenic and immunotoxic properties that cause stunted growth and immune suppression in young mammals (Cardwell, 2000; Gong eí al., 2002).
Arthropod pests also affect crops and livestock, both directly and indirectly. Directly, because a stable supply of food is a prerequisite to human health, and indirectly, because disease incidence in humans is related to nutrition. In livestock, tsetse fly-transmitted trypanosome parasites cause losses in young stock mainly, amounting to an estimated 3 million deaths annually in Africa (Saini, 1999). Hard ticks (Ixodidae) transmit protozoan (theileriosis and babesiosis) as well as rickettsial diseases and predispose animals to secondary infections (Mukhebi, 1992). Inadequate feed supply has an additional impact on animal health.

Crop production is constrained by abiotic factors and pests (Yudelman et al., 1998). In Africa, work on cotton (Baumgärtner et al., 1986), cassava (Gutierrez et al., 1988), rice (Baumgärtner et al., 1989), cowpea (Tamò and Baumgärtner, 1993; Tamò et al., 1993) and maize (Bonato et al., 1999) demonstrates the effect of multiple stresses on yield formation. Climatic variability, particularly in semi-arid areas, limited use of fertilisers and livestock-mediated nutrient transfers from pastureland to croplands interfere with forage crops. Recent studies at the International Institute of Tropical Agriculture (IITA) showed that preharvest pest attacks in maize affects not only the quantity but also the quality of grain, via increased aflatoxin levels, both before and after harvest (Sétamou et al., 1998; Hell et al., 2000). Consequently, solving one biotic problem would also reduce quantitative and qualitative losses by associated organisms and contribute towards the improvement of human and animal health.

Because of the importance of arthropod pests in Africa, the development and implementation of control methods should be an integral part of human health improvement projects. However, based on our experience two aspects are not sufficiently addressed by pest control specialists. 
Although the 21st century has been acclaimed as the century of prevention, an emphasis on curative over preventive methods still prevails in Africa. Plant pest control specialists have recognised that the 'silver bullet' approach is not promising and recommended an integration of control methods instead (Lewis et al., 1998) by relying on existing natural control factors (e.g. Roux and Baumgärtner, 1998; Baumgärtner, 2001). Integrated pest management (IPM) has been defined as a control system that, in the context of the associated environment and the population dynamics of the pest species, utilises all suitable techniques and methods in as compatible a manner as possible and maintains pest populations at levels below those causing economic injury (Flint and van den Bosch, 1981; Dent, 1995).

We discuss here integrated pest management systems with special reference to the African situation, and explore some case studies along the conceptual lines given by Conway (1984) and Kogan et al. (1999). The present discussion does not treat the adoption and innovation diffusion and their social constraints at the farm level, but rather offers a conceptual framework for IPM research in Africa.

\section{INTEgRated Pest Management Systems}

\section{Background}

\section{Integration levels}

Integrated pest management systems are developed for various pest species and species assemblages infesting different systems, relevant for human health improvement, at different ecological, managerial and organisational levels. Kogan et al. (1999), on the basis of ecological and managerial levels, identified IPM systems at three levels of integration. At a fourth level, we propose to combine plant pest ecology and management with the population dynamics and control of human and animal disease vectors (Fig. 1). This level is referred to here as the human health integration level because the human population is an element of the system under consideration.

Integration level I-species/population-level integration: Integration of methods for the control of single species or species complexes within individual crops, a herd of livestock or a human population.

Integration level II-community-level integration: Integration of the impact of multiple pests (insects, pathogens and weeds), individually and in their interactions, on the crop or livestock and the methods for their control.

Integration level III-ecosystem level integration: The integration of multiple pest impacts and their interactions and the method for their control within the context of the entire cropping system, including crops and the surrounding natural plant cover. The ecosystem level integration level may also comprise integrated management systems developed for livestock by considering wildlife as done in tick control, for example (Mwambi et al., $2000 \mathrm{a}, \mathrm{b})$.

Integration level IV-human health level integration: Integration of multiple pest impacts, their interactions and management systems within the context of human health improvement. Among the pest assemblages are infectious diseases and arthropod vectors as well as pests of resources such as livestock, crops, fibres and structural parts of houses. This level is exemplified by integrated disease and resource management systems (Baumgärtner et al., 2001).

The integrated control systems in Fig. 1 are generally developed on the basis of population and community ecology as well as on principles of ecosystem science, in combination with socioeconomics (Baumgärtner and Gutierrez, 1988; Dent, 1995; Gutierrez, 1996; Kogan, 1998; Kogan et al., 1999; Huffaker and Gutierrez, 1999).

\section{Decision-making}

In Fig. 1, the four integration levels are combined with decision-making hierarchies proposed by Conway (1984). Thereby, various end users implement the technologies developed at the different levels. To name a few, farmers, ideally assisted by extensionists and veterinarians, take tactical decisions regarding fields, cropping systems, herd and livestock management. Extensionists are joined by social workers and the health service to implement IPM strategies relevant to farmers and communities. Administrators, policy makers and international 


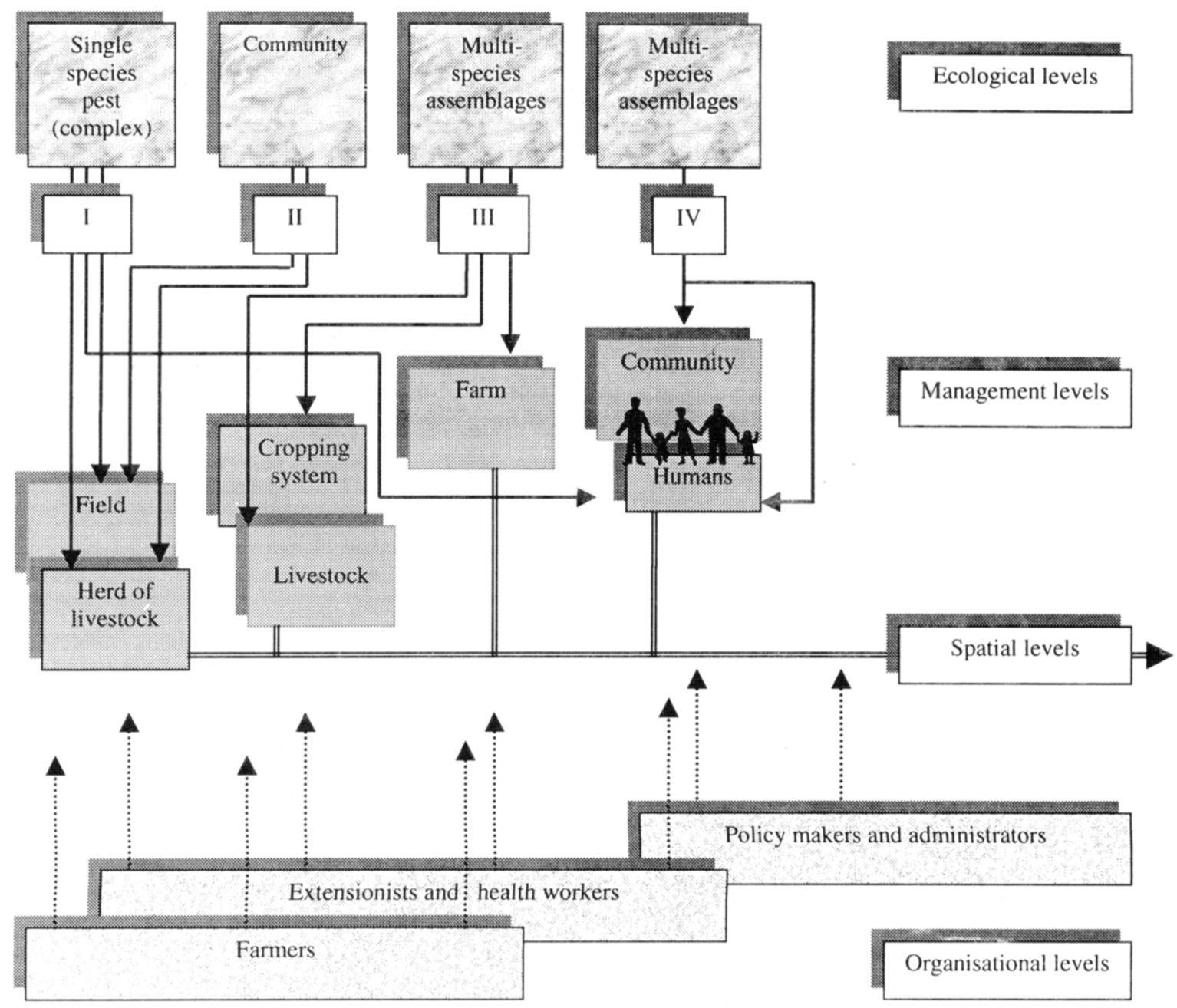

Fig. 1. The structure of the environment considered in integrated pest management (IPM) system design and implementation, based on concepts put forward by Conway (1984) and Kogan et al. (1999)

organisations are addressing issues ranging from farming to international relations issues.

\section{Decision support systems and information dissemination technologies}

Decision-making in the highly structured environment depicted in Fig. 1 is a complicated task and often has to rely on decision support systems and on efficient information dissemination technologies. In entomology, insect informatics deals with the generation, processing and dissemination of insect-related information through the use of modern information technology, which delivers, for example, electronic insect records or checklists, CD products, decision-making support systems, networking, multimedia applications, imaging, information retrieval, management information systems, and databases or knowledge bases (Xia, 1998). Among the commercialised products are CDROMs containing multimedia information systems, insect images, checklists, books, films and Web sites for insect information services ( $\mathrm{Xia}$, 1998).

Computer-aided decision-making support systems for better management of insects have been developed. Recent publications on these subjects include Drapek et al. (1990), Haley et al. (1990), Huber et al. (1990), Knutson et al. (1990), 
Stone and Schaub (1990), Coop et al. (1991), Compton et al. (1992), Mann and Wratten (1992), Thorpe et al. (1992), Bao and Robinson (1993), Rhykerd et al. (1993), Twery et al. (1993), Geyer et al. (1994), Weisz et al. (1994), Alfaro et al. (1996), Gottschalk et al. (1996), Shore et al. (1996), De Groot et al. (1998), Spradling et al. (1998). Most of these systems deal with the identification of insects and their damage, while some provide guidelines for management purposes. In general, however, they do not consider the spatio-temporal dynamics of insects systems as a basis for dynamic decision-making, which is the case in intelligent decision making systems (Xia and Baumgärtner, 1999a).

\section{Status of IPM in Africa}

\section{Background}

Zhetner (1995) wrote an overview on IPM in tropical and sub-tropical Africa. Thereby, African agriculture is characterised by a very large majority of smallscale farmers, who cultivate small landholdings of less than one hectare to a few hectares with several crops grown together. Smallscale farming not only dominates subsistence agriculture but is also the normal situation in cash crop cultivation. Often, farmers do not have titles to the land and ownership of the harvest is not restricted to the ones cultivating it. Another important element is the lack of institutions, which has been identified as a major hindrance to agricultural development in general (Eicher, 1999) and presumably to IPM system development and implementation in particular.

Zhetner (1995) also observes that only a few of the food crops, such as cowpea, yams, millet and sorghum and the cash crops cotton and coffee, are indigenous to Africa. Researchers, farmers and other decision makers apparently have lost interest in cultivating many of the indigenous plant species (see for example, NARC, 1996), apparently without assessing their yield potential and possible desirable attributes for IPM systems. The introduction of crops like maize, rice and cassava took place a few centuries ago, but it is only recently that they are widely grown in Africa. In agreement with Zhetner (1995) we suspect that ecological interrelations have not evolved as to reach the maturity of indigenous agroecosystems. This may explain the changes in the status of some pest organisms or the outbreaks of pests on hitherto unknown host plants (Conlong, 1990; Schulthess et al., 1997). Most serious pests are indigenous, but there has been a large number of accidental introductions making classical biological control an important IPM component (Herren and Neuenschwander, 1991; Zhetner, 1995).

Saini (1998) presents case studies of IPM systems in Africa, such as maize, cotton and vegetable pests. African farmers still rely on many traditional methods, including the use of botanicals, for pest control. The disregard of valid traditional methods and unilateral reliance on synthetic pesticides, exemplified by cotton production systems in the Gezira, Sudan, (Eveleens, 1983), can have serious ecological and economic drawbacks (Flint and van den Bosch, 1981) which should be considered when developing high input cropping systems. To meet zero levels for pesticide residues in export vegetables, many African farmers will have to shift from a pesticide-dominated system to biologically intensive IPM or organic production systems.

\section{Information dissemination system and decision-} making support systems in Africa

In 1995, the International Centre of Insect Physiology and Ecology (ICIPE) initiated several information systems and information networking activities. Among them is the Arthropod Information Network in Africa (AINA) and database activities. Through the support of the United Nations Development Programme (UNDP), ICIPE established the Pest Management Research and Development Network (PESTNET) in 1986 following discussions with several East African countries (Xia, 1998). PESTNET aimed at improving the food security of developing countries in the tropics and sub-tropics, especially in Africa, by relying on the integrated pest management (IPM) concept for a rational control of insect pests of crops and of vectors of human and animal diseases. The relevant information is disseminated through a network of concerned member countries (Burundi, Côte d'Ivoire, Ethiopia, Kenya, Malawi, Nigeria, Somalia, Sudan, Tanzania, Uganda, Zambia and Zimbabwe). Under PESTNET a Pest Management Documentation and Information System and 
Service (PMDISS) has been established, and several IPM projects in the member countries were successfully carried out. Both scientists and IPM practitioners received training in information exchange (Xia, 1998). In 1996, additional support from the United States Agency for International Development (USAID) approved the reorganisation of PESTNET as an Africa-wide IPM information networking project.

Informatics has revolutionised the way information is disseminated. More and more information has been disseminated electronically through the Internet. Entomologists worldwide have started to develop insect information systems (http:/ / www.ent.iastate.edu/List/) and are currently demonstrating that web-based interfaces are the easiest dissemination media for the final products. Web-based information products can also be published on CD-ROM for off-line browsing. At ICIPE, a new Insect Informatics Initiative started in early 1998. It is planned according to the needs and interests of a wide range of users. An important component of this initiative is the Web-Based Intelligent Insect Management Information Systems, which is designed to facilitate the task of users ranging from policy makers, extensionists and farmers.

Remote sensing, geographical information technology and other areas of Informatics need to be integrated into the development of webbased decision-making support systems. For this purpose an Africa Remote Sensing Data Bank has been established at ICIPE. The data bank is accessible on ICIPE Informatics server (http:// informatics.icipe.org/databank.htm) and has a mirror site at North Carolina State University (http:/ / pestdata.ncsu.edu/informatics / databank.htm), which makes the data accessible to external users. Currently, concise simulation models are being developed and adapted to African conditions as the basis for the development of intelligent decision-making tools addressing the wide range of end users depicted in Fig. 1 (Xia and Baumgärtner, 1999a,b).

\section{IPM system development and implementation}

In Africa, there are examples on the application of modern ecological methods, including geographical information and mathematical models, to population dynamics and disease epidemiology for the design of control systems, such as for ticks (Randolph and Rogers, 1995;
Sutherst et al., 1995; Mwambi et al., 2000a,b; Randolph, 2000), tsetse flies (Rogers, 2000), mosquitoes (Hay et al., 2000) and pests of crops (Bonato et al., 1999) and stored products (Holst et al., 2000). Components of IPM schemes such as different pest control technologies are developed and implemented by farmers and various institutions such as farmers' associations, nongovernmental organisations (NGOs), national agricultural research institutions (NARES), international agricultural research centres (IARCs), and international organisations such as the Food and Agriculture Organization of the United Nations (FAO) and World Health Organization (WHO). However, the relevant information is scattered among innumerable publications, often difficult to access, and little attempt has been made so far to compile a comprehensive overview. Nevertheless, the information available indicates that the integration of components into IPM schemes has been achieved in few examples only (e.g. Roux and Baumgärtner, 1998).

An IARC system-wide IPM (SP-IPM) group coordinates IPM-related work carried out at different IARC centres (SP-IPM, 2000). Some of the IPM projects are presented in the centre's annual reports or in the system-wide IPM group's highlights (SP-IPM, 2000). Regretfully, the compilation of a comprehensive list of IPM projects is still incomplete ( $R$. Markham, excoordinator SP-IPM, IITA, Ibadan, Nigeria, pers. commun.).

\section{Case studies}

As in Kogan et al. (1999), the choice of case studies is based on an attempt to highlight particularly relevant aspects of the relationship of ecology and IPM, and is no reflection of the level of achievement in IPM development, implementation, or success by contrast to other systems. Here, we exclusively refer to a few illustrative IPM systems, familiar to us, in various stages of development (Table 1).

Integration level I: The potato tuberworm, Phthorimaea operculella Zeller, infests stored potatoes in Tunisia's rustic shelters (Roux and Baumgärtner, 1998). The IPM systems under development rely on a combination of different control methods with emphasis on mechanical and biological control (Table 1). Noteworthy, the IPM system takes into account the risk a grower 
faces when relying on naturally occurring biological control, and makes recommendations regarding the use of virus applications. The onion thrips IPM system under development also relies on naturally occurring biological control factors, but the field situation apparently offers a wider range of control options to be possibly incorporated into the IPM system than the storage situation with $P$. operculella. Among them are host plant resistance as well as cultural methods combined with microbial control (Table 1). The implementation of both IPM systems, particularly with respect to the structured environment of Fig. 1 , apparently requires additional work. Kogan et al. (1999) refers to the tick management system in Australia, with reference to Africa, as an integration level I example from medical entomology.

Integration level II: Although at some locations only one species may be found, we focus on tsetse fly communities of species attacking livestock and transmitting trypanosomosis (Table 1). In Ethiopia, for example, mass trapping operations with the involvement of the villagers, were a successful method of tsetse control (Getachew, 1998). There have been attempts to primarily rely on genetic control methods following mass trapping operations. More comprehensive systems under development combine mass trapping methods with herd management. However, Saini (1999) argued that a combined pathogen/vector management system adapted to local conditions and put into the context of sustainable rural development, is a more promising strategy than regional or continental efforts relying on a limited number of control options. If the pest control system is also considering wildlife sometimes confined to reserves or extended to human sleeping sickness transmission, integration levels III or IV are addressed.

Integration level III: The IPM system under development for various maize stemborer species relies heavily on host plant resistance and biological control methods including the introduction of exotic parasitoids (Overholt et al., 1994; 1997). Habitat management strategies have been developed for influencing stemborer infestations, for enhancing parasitoid effects and for weed control (Khan et al., 1997a,b; Table 1). The IPM system also considers uncultivated grassland and is being completed with economic threshold studies and a better integration of habitat management options and classical biological control. The system is being implemented in eastern and southern Africa where it has been widely accepted by farmers.

Integration level III-IV: Mycotoxin-producing fungi which cause deterioration of food and feeds are between integration levels III and IV because they are often vectored by a complex of pre- and post harvest arthropod crop pests and they seriously affect human and animal fitness. Studies in Benin show a coincidental appearance of growth faltering and increased illness (symptoms associated with sub-acute mycotoxin exposure) in weaning children fed on foods with a high risk of mycotoxin contamination (Cardwell, 2000; Gong et al., 2002). Recent studies at the International Institute of Tropical Agriculture (IITA) showed borers also predisposes maize to infestations by storage beetles, infections by Aspergillus spp. and F. verticillioides and subsequent contamination of mycotoxins (Sétamou et al., 1998; Cardwell et al., 2000; Hell et al., 2000). Furthermore, it was shown for $F$. verticillioides that some lepidopteran and coleopteran pest species not only vector the fungus but ovipositing females are also attracted to infected plants and the progenies feeding on such plants have higher survival and higher fecundity (Schulthess et al., 2002; Ako et al., 2003). Because the different biotic problems are interrelated emphasis is given to understanding the interactions between the different pest organisms in space and time, from planting, harvest, storage and processing of foods and feeds, and on the effect of the abiotic environment on them (Cardwell et al., 2000; Schulthess et al., 1997; Schulthess et al., 2002; Sétamou et al., 1998; Hell et al., 2000). Thus, this project also considers the indirect effect of insect damage on blood aflatoxin concentration in infants and their effect on growth and fitness (Gong et al., 2002).

Biological control (introduction BC or enhancing naturally occurring control for stemand cob borers; classical or microbial control for post harvest pests; competitive niche displacement for Aspergillus spp. or the use of fungal antagonists for $F$. verticillioides) and habitat management/cultural control (for all pest organisms) technologies as well as host plant resistance (for all pest organisms) have been developed and the efficacy botanicals (for borers) and Mycosorb $\bowtie$ (for neutralising aflatoxin) have 


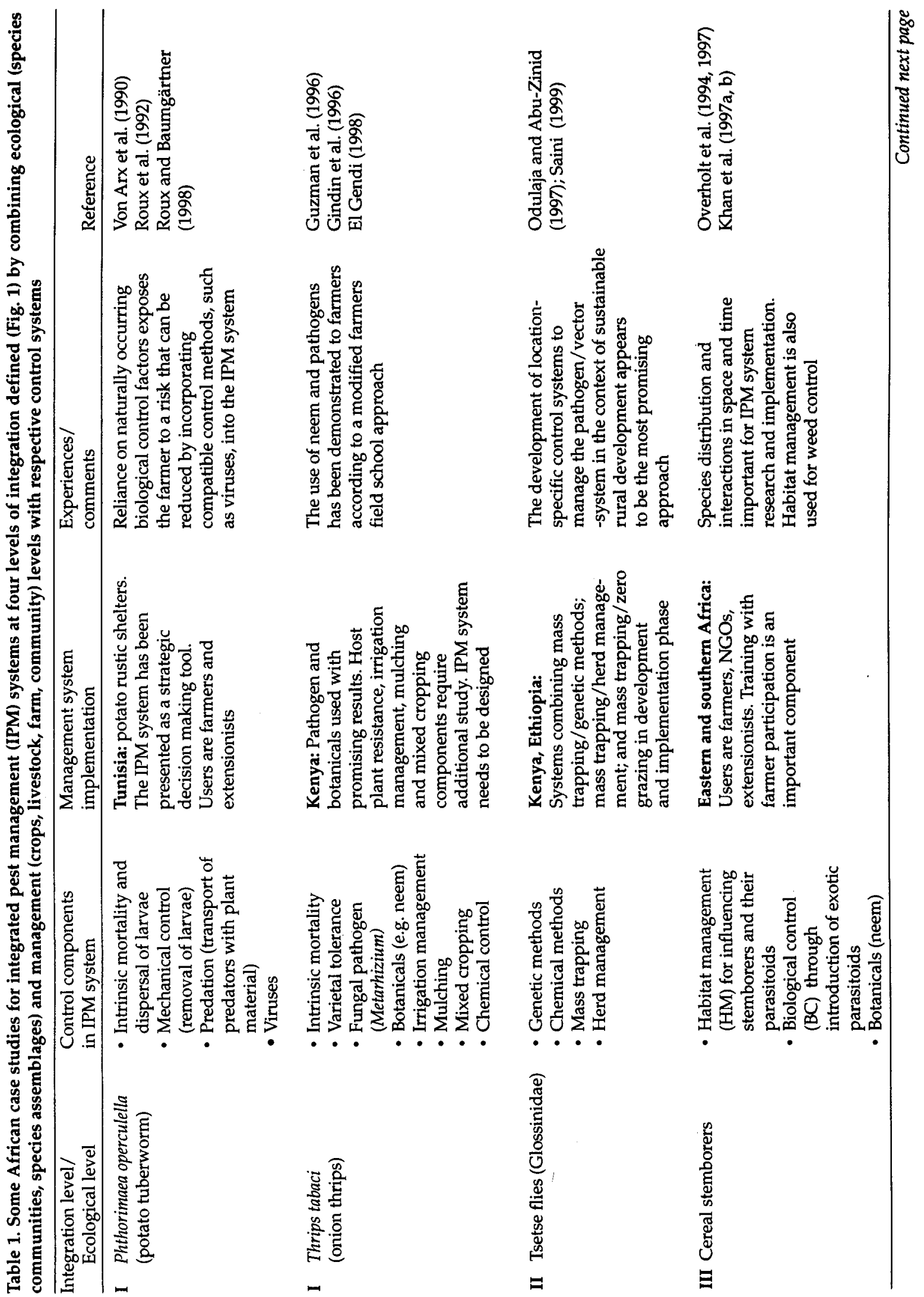




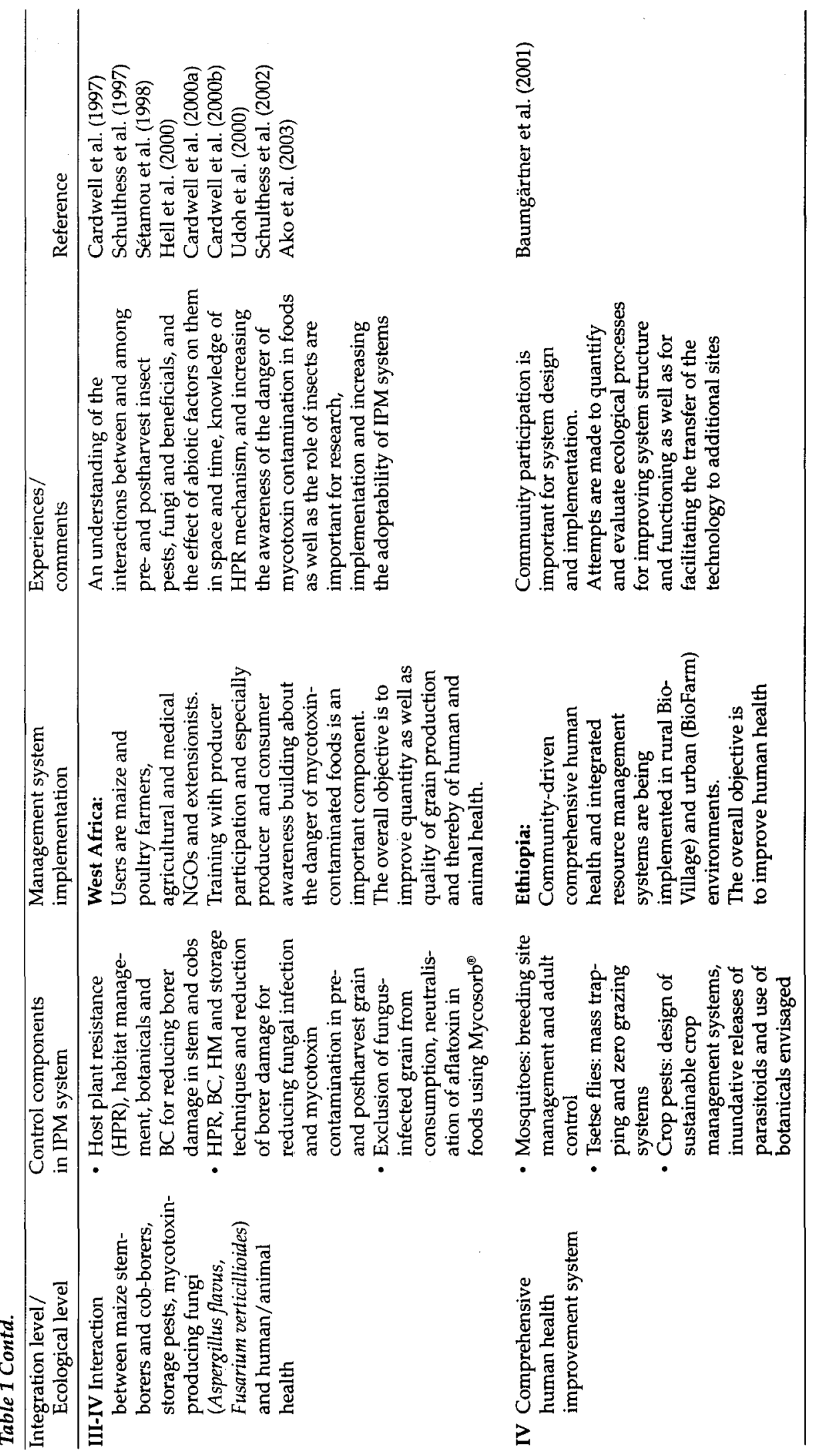


been investigated. For mycotoxins, emphasis is given to nutrition education and conducting public information campaigns about the importance of consuming only good quality grain.

Integration level $I V$ : The integrated management scheme relies on the study and management of ecosystems composed of three sets of subsystems namely, disease vector subsystems, resource management subsystems, and a decision support system (Baumgärtner et al., 2001). Two ecosystems in rural and urban Ethiopia are studied and managed with the objectives of enhancing both sustainability and ecosystem services (Baumgärtner et al., 2002). Briefly, environmental sustainability is achieved by holding the scale of the human economic system within the biophysical limits of the ecosystem (Goodland, 1995). Ecosystem services are conditions and processes through which natural ecosystems sustain and fulfill human life (Daily, 1997). Among them are (1) production of goods, e.g. forage, timber, fibre, pharmaceuticals; (2) maintenance of biodiversity; (3) life support functions such as the purification of air and water, the mitigation of floods and droughts, the decomposition of wastes, pollination, pest control, and moderation of weather extremes; (4) support of diverse human cultures; and (5) provision of aesthetic beauty and intellectual stimulation that lift the human spirit.

Briefly, an integrated control scheme implemented with community participation comprises a system of grazing measures, including zero grazing, to disrupt the spatiotemporal coincidence between livestock and disease vectors, tsetse fly mass trapping technology and drug administration to sick animals. The integrated control scheme of malaria is, in the initial phase, a combination of mosquito breeding site management methods, protection of humans from adult mosquitoes by screening the houses and the administration of drugs against the malarial parasites. A sustainable resource system requires the reorganisation of the matter flow between producers (plants), consumers (livestock, humans, fish) and decomposers. The original system was unsustainable as it linked consumers to producers but the processes of organic matter decomposition and plant fertilisation were not adequately established (Baumgärtner et al., 2002). The design and implementation of integrated ecosystem management schemes on the basis of ecological principles (e.g. Curry and Feldman, 1987; Baumgärtner and Gutierrez, 1988; Gutierrez, 1996; Di Cola et al., 1998, 1999), the adoption of appropriate technologies, the enhancement of environmental sustainability and ecosystem services, and community participation resulted to fast improvements in human health status (Baumgärtner et al., 2002).

\section{Conclusion}

Conway (1984) and Kogan et al. (1999) proposed useful concepts for assigning IPM systems to different decision-making levels as well as to different pest control integration levels, combining ecological (species, communities, species assemblages) and management levels (crops, cropping systems, farms, communities) with respective control systems. These levels produce a highly structured environment for decision making, in which the use of modern information technologies, for information dissemination and exchange, becomes very important. In Africa, farmers, IPM specialists including researchers and policy makers would benefit from additional investments into this important area. In the design of IPM systems preventive methods should be preferred over curative methods, and the advantage of compatible as well as of biologically sensitive methods should be recognised.

Case studies show that IPM systems are under development and implementation at four integration levels. Our experience indicates, however, that most work is done on integration level 1 addressing a single pest or pest complex attacking a crop, a herd of livestock or a population of humans and the control measures undertaken. Coordinated efforts to develop and implement supplementary IPM systems at higher levels are important elements in integrated pest and resource management and a further contribution to human health improvement and poverty alleviation.

Acknowledgements-Drs W.A. Overholt, S. Sithanantham and R. Saini, ICIPE, Nairobi, assisted in the manuscript's preparation and made available important literature information. Mrs Veronica Baumgärtner's help in editing the manuscript is appreciated. Thanks go to Drs Getachew Tikubet, ICIPE, Addis Ababa, and Richard Markham, IITA, Ibadan for useful comments. 


\section{REFERENCES}

Ako M., Schulthess F., Gumedzoe M. Y. D. and Cardwell K. F. (2003) The effect of Fusarium verticillioides Sacc. (Nirenberg) or oviposition behaviour and bionomics of lepidopteran and coleopteran pests attacking the stem and cobs of maize in West Africa. Entomol. Exp. Appl. 106, 201-210.

Alfaro R. I., Brown R. G., Mitchell K. J., Polsson K. R. and MacDonald R. N. (1996) SWAT: A decision support system for spruce weevil management. FRDA Report 260, 31-41.

Anonymous (1996) Concise Science Dictionary. $3^{\text {rd }}$ edition, Oxford University Press. 794 pp.

Bao N. and Robinson W. H. (1993) Computer aided decision support system for American cockroach management in the urban environment, pp. 393-399. In Proceedings of the 1st International Conference on Insect Pests in the Urban Environment/International Conference on Insect Pests in the Urban Environment, 30 June-3 July 1993, Cambridge, UK.

Baumgärtner J. (2001) Biodiversity that mitigates pests in agroecosystems. In Biodiversity Planning Support Programs. Global Environment Facility. UNEP-BPSP Thematic Studies on the Integration of Biodiversity into National Agricultural Sectors. UNEP BPSP, Nairobi, Kenya.

Baumgärtner J. and Gutierrez A. P. (1988) Simulation techniques applied to crops and pest models, pp. 175-214. In Parasitis 88. Proceedings of a Scientific Congress, Barcelona, October 25-28 (Edited by R. Cavalloro and V. Delucchi). Boletin de Sanidad Vegetal, fuera de serie, 17.

Baumgärtner J., Bieri J., Buffoni G., Gilioli G., Gopalan H. N. B., Greiling J., Tikubet G. and van Schayk I. M. C. J. (2001) Human health management in subSaharan Africa through integrated management of arthropod transmitted diseases and natural resources. Cadernos de saúde puiblica (reports in public health) 17, 17-46.

Baumgärtner J., Delucchi V., von Arx R. and Rubli D. (1986) Whitefly (Bemisia tabaci Genn., Stern., Aleyrodidae) infestation patterns as influenced by cotton, weather and Heliothis: Hypothesis testing by using simulation models. Agric., Ecosyst. Environ. 17, 49-59.

Baumgärtner J., Getachew T., Gilioli G. and Bieri M. (2002) The design and implementation of integrated disease and resource management schemes for human health improvement in sub-Saharan Africa. Proceedings Ethio-Forum 2002, Addis Ababa, Ethiopia (in press).

Baumgärtner J., Regev U., Rahalivavololona N., Graf B., Zahner Ph. and Delucchi V. (1989) Rice production in Madagascar: Regression analysis with particular reference to pest control. Agric., Ecosyst. Environ. 30, $37-47$.
Begon M., Harper J. L. and Townsend C. R. (1996) Ecology. 3rd edition. Blackwell Science, Oxford. 1068 pp.

Bonato O., Schulthess F. and Baumgärtner J. (1999) Simulation model for maize crop growth based on acquisition and allocation functions for carbohydrate and nitrogen. Ecological Modelling 124, 13-28.

Cardwell K. F. (2000) Mycotoxin contamination of foods in Africa: Anti-nutritional factors. Food Nutr. Bull. 21, 488-492.

Cardwell K. F., Kling J. G., Maziya-Dixon B. and BosquePérez N. (2000) Interactions between Fusarium verticillioides, Aspergillus flavus and insects in improved maize populations in lowland Africa. Phytopathology 90, 276-284.

Cardwell K. F., Schulthess F., Ndemah R. and Ngoko Z. (1997) A systems approach to assess crop health and maize yield losses due to pest and diseases in Cameroon. Agric., Ecosyst. Environ. 65, 33-47.

Compton J. A. F., Tyler P. S., Mumford J. D., Norton G. A., Jones T. H. and Hindmarsh P. S. (1992) Potential for an expert system on pest control in tropical grain stores. Trop. Sci. 32, 295-303.

Conlong D. E. (1990) A study of pest-parasitoid relationships in natural habitats: An aid towards the biological control of Eldana saccharina (Lepidoptera: Pyralidae). Proc. S. Africa Sugar Technol. Assoc. 64, 111-115.

Conway G.R. (1984) Introduction, pp. 1-11. In Pest and Pathogen Control. Strategic, Tactical and Policy Models (Edited by G. Conway). Wiley, New York.

Coop L. B., Croft B.A., Murphy C. F. and Miller S. F. (1991) Decision support system for economic analysis of grasshopper treatment operations in the African Sahel. Crop Prot. 10, 485-495.

Curry G. L. and Feldman R. M. (1987) Mathematical Foundations of Population Dynamics. Texas A\&M University Press, College Station. 246 pp.

Daily G. C. (1997) Nature's Services. Societal Dependence on Natural Ecosystems. Island Press, Washington, DC. $416 \mathrm{pp}$.

De Groot P., Schnekenburger F., Fleming R. A. and Turgeon J. J. (1998) CONESYS: A data collection, database, and decision support system for making insect pest management decisions in seed orchards. Northern J. Appl. For. 15, 154-157.

Dent D. (1995) Integrated Pest Management. Chapman \& Hall, London. 356 pp.

Di Cola G., Gilioli G. and Baumgärtner J. (1998) Mathematical models for age-structured population dynamics: An overview, pp. 45-61. In Population and Community Ecology for Insect Management and Conservation (Edited by J. Baumgärtner, P. Brandmayr and B. F. J. Manly Bryan). Balkema Publishers, Rotterdam.

Di Cola G., Gilioli G. and Baumgärtner J. (1999) Mathematical models for age-structured population dynamics, pp. 503-536. In Ecological Entomology, $2^{\text {nt }}$ edition (Edited by C. B. Huffaker and A. P. Gutierrez). Wiley, New York. 
Drapek R. J., Calkin J. A. and Fisher G. C. (1990) A hazelnut pest management expert system. Acta Horticult. 276, 21-25.

Ehler L.E. (2000) Farmscape ecology of stink bugs in Northern California. Entomol. Soc. America. 59 pp.

Eicher C.K. (1999) Institutions and the African Farmer. Issues in Agriculture 14. CGIAR (Consultative Group on International Agricultural Research), Washington.

El Gendi S. M. (1998) Population fluctuations of Thrips tabaci Lind on onion plants under Fayoum environmental conditions. J. Agric. Sci. 6, 267-276.

Eveleens K. G. (1983) Cotton-insect control in the Sudan Gezira: An analysis of a crisis. Crop Prot. 2, 273-287.

Flint M. L. and van den Bosch R. (1981) Introduction to Integrated Pest Management. Plenum Press, New York. 240 pp.

Gebre Amlak A., Sigvald R. and Peterson J. (1989) The relationship between sowing date, infestation and damage by the maize stalk borer, Busseola fusca (Noctuidae), on maize in Awassa, Ethiopia. Trop. Pest Manage. 35, 143-145.

Geyer M. W., Sequeira R. A., Paradice D. B., Fowler G. C., Miller C. and Staten R. T. (1994) Cotton pest management: A knowledge-based system to handle information input overload. AI Applic. 8, 1-20.

Gindin G., Barash I., Raccah B. S., Ben Zeev L. S., Klein M., Jenser C. R. and Adam L. (1996) The potential of some entomopathogenic fungi as biocontrol agents against the onion thrips, Thrips tabaci and the western flower thrips, Frankliniella occidentalis. Folia Entomol. Hungariaa 62, 37-42.

Gong Y. Y., Cardwell K., Hounsa A., Egal S., Turner P. C., Hall A. J. and Wild C. P. (2002) Cross-sectional study of dietary aflatoxin exposure and impaired growth in young children from Benin and Togo, West Africa. British Med. J. 325, 20-21.

Goodland R. (1995) The concept of environmental sustainability. Annut. Rev. Ecol. Syst. 26, 1-24.

Gottschalk K. W., Thomas S. J., Twardus D. B., Ghent J. H., Colbert J. J. and Teske M. E. (1996) GypsES: A decision support system for gypsy moth management. FRDA Rep. 260, 1-8.

Gutierrez A. P. (1996) Applied Population Ecology. A Supplydemand Approach. John Wiley, New York. 300 pp.

Gutierrez A. P., Wermelinger B., Schulthess F., Baumgärtner J., Yaninek J. S., Herren H. R., Neuenschwander P., Löhr B., Hammond W. N. O. and Ellis C.K. (1988) An overview of a systems model of cassava and cassava pests in Africa. Insect Sci. Applic. 8, 919-924.

Guzman N. S. P., Salazar R. P., Troche Z. and De la Cruz J. (1996) Life cycle, habits and behaviour of Thrips tabaci Linderman in onions (Allium cepa). Revista de Entomol. 22, 93-98.

Haley S., Currans K. G. and Croft B. A. (1990) A computer aid for decision-making in apple pest management. Acta Horticult. 276, 27-34.
Hay S. I., Omumbo J. A., Craig M. H. and Snow R. W. (2000) Earth observation, geographic information systems and Plasmodium falciparum malaria in subSaharan Africa, pp. 174-215. In Remote Sensing and Geographical Information Systems in Epidemiology. (Edited by S. I. Hay, S. E. Randolph and D. J. Rogers). Advances in Parasitology 47. Academic Press, London.

Hell K., Cardwell K. F., Sétamou M. and Schulthess F. (2000) Influence of insect infestation on aflatoxin contamination of stored maize in four agroecological regions in Benin. African Entomol. 8, 169-177.

Herren H. R. and Neuenschwander P. (1991) Biological control of cassava pests in Africa. Annu. Rev. Entomol. $36,257-283$.

Holst N., Meikle W. G. and Markham R. H. (2000) Grain injury models for Prostephanus truncatus (Coleoptera: Curculionidae) and Sithophilus zeamais (Coleoptera: Curculionidae) in rural maize stores in West Africa. J. Econ. Entomol. 93, 1338-1346.

Huber B., Nyrop J. P., Wolf W., Reissig H., Agnello A. and Kovach J. (1990) Development of a knowledgebased system supporting IPM decision making in apples. Comp. Electron. Agric. 4, 315-331.

Huffaker C. B. and Gutierrez A. P. (1999) Ecological Entomology. $2^{\text {nd }}$ edition, Wiley, New York. 756 pp.

Kettle D. S. (1990) Medical and Veterinary Entomology. CAB International, Wallingford. $658 \mathrm{pp}$.

Khan Z. R., Ampong-Nyarko K., Chiliswa P., Hassanali A., Kimani S., Lwande W., Overholt W., Pickett J. A., Smart L. E., Wadhams L. C. and Woodcock C. (1997a) Intercropping increases parasitism. Nature 388,631 632.

Khan Z. R., Chiliswa P., Ampong-Nyarko K., Smart L. E., Polaszek A., Wandera J. and Mula M.A. (1997b) Utilisation of wild gramineous plants for management of cereal stemborers in Africa. Insect Sci. Applic. 17, 143-150.

Knutson L., Sailer R. I., Murphy W. L., Carlson R. W. and Dogger J. R. (1990) Computerized database on immigrant arthropods. Ann. Entomol. Soc. Am. 83, $1-8$.

Kogan M. (1998) Integrated pest management: Historical perspectives and contemporary development. Annu. Rev. Entomol. 43, 243-270.

Kogan M., Croft B. A. and Sutherst R. F. (1999) Applications of ecology for integrated pest management, pp. 681-736. In Ecological Entomology $2^{\text {nd }}$ edition (Edited by C.B. Huffaker and A.P. Gutierrez). Wiley, New York.

Lewis W. J., van Lenteren J. C., Pathak S. C. and Tumlinson III J. H. (1998) A total system approach to sustainable pest management. Proceedings of National Academy of Sciences 94, 12243-12248.

Mann B. P. and Wratten S. D. (1992) A computer-based advisory system for control of the summer pests of winter oilseed rape in Britain. Crop Prot. 11, 561-571.

Mukhebi A. W. (1992) Economic impact of theileriosis and its control in Africa, pp. 379-403. In The 
Epidemiology of Theilerosis in Africa (Edited by R. A. I. Norval, B. D. Perry and A. S. Young). Academic Press, London.

Munkvold G. P., Hellmich R. L. and Showers W. B. (1997) Reduced Fusarium ear rot and symptomless infection in kernels of maize genetically engineered for European corn borer resistance. Phytopathology 87, 1071-1077.

Mwambi H.G., Baumgärtner J. and Hadeler K. P. (2000a) Ticks and tick-borne diseases: A vector-host interaction model for the brown ear tick (Rhipicephalus appendiculatus). Stat. Meth. Med. Res. 9, 279-301.

Mwambi H. G., Baumgärtner J. and Hadeler K. P. (2000b) Development of a stage-structured analytical population model for strategic decision making: The case of ticks and tick-borne diseases. Rivista Matematica della Università di Parma 3, 157-169.

NARC [National Research Council] (1996) Lost Crops of Africa. Vol. I Grains. Board on Science and Technology for International Development. National Research Council. National Academy Press, Washington.

Odulaja A. and Abu-Zinid I. M. (1997) The relative efficiencies of Latin square and randomized complete block designs for insect trapping experiments: An investigation using field data on tsetse flies. Ecol. Entomol. 22, 184-188.

Otieno L. H. and Saini R. K. (Eds) (1990) Tsetse Population and Behaviour. Proceedings of the International Study Workshop on Tsetse Population and Behaviour, 610 August 1989. Insect Sci. Applic. Special Issue 11, $257-461$.

Overholt W. A., Ngi-Song A. J., Kimani S., Mbapila J., Lammers P. S. and Kioko E. (1994) Ecological considerations of the introduction of Cotesia flavipes Cameron (Hymenoptera: Bracondiae) for biological control of Chilo partellus (Lepidoptera: Pyralidae), in Africa. Biocontr. News Info. 15, 19N-24N.

Overholt W. A., Ngi-Song A. J., Omwega C. O., KimaniNjogu S. W., Mbapila J., Sallam M. N. and Ofomata V. (1997) A review of the introduction and establishment of Cotesia flavipes Cameron (Hymenoptera: Braconidae) in East Africa for biological control of cereal stemborers. Insect Sci. Applic. 17, 79-88.

Randolph S.E. (2000) Ticks and tick-borne disease systems in space and from space, pp. 217-243. In Remote Sensing and Geographical Information Systems in Epidemiology (Edited by S. I. Hay, S. E. Randolph and D. J. Rogers). Advances in Parasitology 47. Academic Press, London.

Randolph S. E. and Rogers D. J. (1995) Towards new population models as tools for the control of African ticks and tick-borne diseases, pp. 2-35. In Proc. Conf. Tick-borne Pathogens at the Host-Vector Interface: A Global Perspective (Edited by L. Coons and M. Rothschild).

Rhykerd L. M., Rhykerd R. L., Engel B. A., Wilson M. C. and Rhykerd C. L. (1993) A knowledgepro decision support system for detecting and managing the major insect pests of Medicago sativa L. Proceedings/ American Forage and Grassland Council 2, 34-37.

Rogers D. J. (2000) Satellites, space, time and the African trypanosomiases, pp. 129-171. In Remote Sensing and Geographical Information Systems in Epidemiology (Edited by S. I. Hay, S. E. Randolph and D. J. Rogers). Advances in Parasitology 47. Academic Press, London.

Roux O. and Baumgärtner J. (1998) Evaluation of mortality factors and risk analysis for the design of an integrated pest management system. Ecological Modelling 109, 61-75.

Roux O., von Arx R. and Baumgärtner J. (1992) Estimating potato tuberworm (Lepidoptera: Gelechiidae) damage in stored potatoes in Tunisia. J. Econ. Entomol. 85, 2246-2250.

Saini R. K. (Ed.) (1998) Tropical Entomology. Proceedings of the $3^{\text {rd }}$ International Conference on Tropical Entomology, Nairobi, Kenya. ICIPE Science Press, Nairobi, Kenya. 409 pp.

Saini R. K. (1999) Fighting Africa's deadly fly - new ecofriendly solutions for tsetse management. Accomplishments of the European Union-funded project on interactive development and application of sustainable tsetse management technologies for agropastoral communities in Africa. ICIPE Science Press, Nairobi. $11 \mathrm{pp}$.

Schulthess F., Bosque-Pérez N.A., Chabi-Olaye A., Gounou S., Ndemah R. and Goergen G. (1997) Exchanging natural enemies species of lepidopterous cereal stemborers between African regions. Insect Sci. Applic. 17, 97-108.

Schulthess F., Cardwell K. F. and Gounou S. (2002) The effect of endophytic Fusarium verticillioides on infestation of two maize varieties by lepidopterous stemborers and coleopteran grain feeders. Phytopathol. 92, 120-128.

Sétamou M., Cardwell K. F., Schulthess F. and Hell K. (1998) Effect of insect damage to maize ears, with special reference to Mussidia nigrivenella (Lepidoptera; Pyralidae), on Aspergillus flavus (Deuteromycetes; Monoliales) infection and alfatoxin production in maize before harvest in the Republic of Benin. J. Econ. Entomol. 91, 433-438.

Shore T. L., Riel W.G. and Safranyik L. (1996) A decision support system for the mountain pine beetle in lodgepole pine stands. FRDA Rep. 260, 25-30.

SP-IPM (2000) System-wide Program on Integrated Pest Management. Progress Report 1998-2000. The SPIPM Coordinator, International Institute of Tropical Agriculture, IITA, Ibadan.

Spradling S. L., Olson J. K., Coulson R. N. and Lovelady C. N. (1998) A geographic information system approach to evaluating the effects of the endangered species protection program on mosquito control. $J$. American Mosq. Contr. Assoc. 14, 137-147.

Stone N. D. and Schaub L. P. (1990) A hybrid expert 
system/simulation model for the analysis of pest management strategies. AI Applic. Nat. Resour. Manage. 4, 17-26.

Sutherst R. W., Floyd R. B., Maywald G. F. and Yeomans A. F. (1995) Modelling for management of ticks, pp. 36-42. In Proceedings of a Conference on Tick-borne Pathogens at the Host-Vector Interface: A Global Perspective (Edited by L. Coons and M. Rothschild).

Tamò M. and Baumgärtner J. (1993) Analysis of the cowpea agro-ecosystem in West Africa. I. A demographic model for carbon acquisition and allocation in cowpea Vigna unguiculata (L.) Walp. Ecological Modelling 65, 95-121.

Tamò M., Baumgärtner J. and Gutierrez A. P. (1993) Analysis of the cowpea agro-ecosystem in West Africa. II. Modelling the interactions between cowpea and the bean flower thrips Megalurothrips sjostedti (Trybom) (Thysanoptera, Thripidae). Ecological Modelling 70, 89-113.

Thorpe K. W., Ridgeway R. L. and Webb R. E. (1992) A computerized data management and decision support system for gypsy moth management in suburban parks. Comp. Electr. Agric. 6, 333-345.

Twery M. J., Elmes G. A., Schaub L. P., Foster M. A. and Saunders M.C. (1993) GypsES: A decision support system for gypsy moth management. General Technical Report NE-USDA, Forest Service, Northeastern Forestry Experimental Station. 175, 56-64.

Udoh J. M., Ikotun T. and Cardwell K. F. (2000) Storage structures and aflatoxin content of maize in five agroecological zones of Nigeria. J. Stored Prod. Res. 36, 187-201.

Von Arx R., Roux O. and Baumgärtner J. (1990) Tuber infestation by potato tubermoth, Phthorimaea operculella (Zeller) at potato harvest in relation to farmers's practices. Agric., Ecosyst. Environ. 31, 277292.

Weisz R., Saunders M., Smilowitz Z., Huang H. and Christ B. (1994) Knowledge-based reasoning in integrated resistance management: The Colorado potato beetle (Coleoptera: Chrysomelidae). J. Econ. Entomol. 87, 1384-1399.
WHO [World Health Organization] (1995) Vector control for malaria and other mosquito-borne diseases. Report of a WHO Study Group. WHO Technical Report Series 857. World Health Organization, Geneva.

Windels C. E., Windels M. B. and Kommedahl T. (1975) Association of Fusarium species with picnic beetles on corn ears. Phytopathology 66, 328-331.

WRI [World Resources Institute] (1998) World Resources 1998-99. A Guide to the Global Environment: Environmental Change and Human Health. A joint publication by the World Resources Institute, the United Nations Environment Programme and the United Nations Development Programme. Oxford University Press, Oxford. $384 \mathrm{pp}$.

Xia Y. (1998) PESTNET at ICIPE and Insect Informatics, pp. 133-137. Workshop Proceedings of the Integrated Pest Management Communications and Information Workshop for Eastern and Southern Africa (ICWESA), Nairobi, Kenya, 1-6 March 1998.

Xia Y. and Baumgärtner J. (1999a) Web-based intelligent insect management information system. 2nd MODSS '99 (Multi-Objective Decision Support System), Brisbane, Australia, 1-6 August 1999. http: //informatics.icipe.org modds99_full_paper.doc

Xia Y. and Baumgärtner J.(1999b), ICIPE Insect Informatics Initiative: An Integrated Approach for Insect Information Generation, Processing and Dissemination, pp. 31-39. In Role and Potential of IT Systems and Communication Networks for International Development (Edited by A. Loeper et al.). Universität Bonn-ILB, Germany.

Yudelman M., Ratta M. A. and Nygaard N. (1998) Pest management and food production. Looking to the future. Food, Agriculture, and the Environment Discussion Paper 25. International Food Policy Research Institute, Washington.

Zhetner O. (1995) Practice of integrated pest management in tropical and sub-tropical Africa: An overview of two decades (1970-1990), pp. $1-67$. In Integrated Pest Management in the Tropics: Current Status and Future Prospects (Edited by A. N. Mengech, K. N. Saxena and H. N. B. Gopalan). Wiley, New York. 